\title{
Exotic species of zooplankton in the Upper Paraná River floodplain, Daphnia lumholtzi Sars, 1885 (Crustacea: Branchiopoda)
}

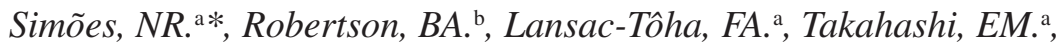 \\ Bonecker, CC. ${ }^{\text {a }}$,Velho, LFM. ${ }^{\mathrm{a}}$ and Joko, CY. ${ }^{\mathrm{a}}$ \\ aPrograma de Pós-Graduação em Ecologia de Ambientes Aquáticos Continentais, Núcleo de Pesquisas em Limnologia, \\ Departamento de Biologia, Ictiologia e Aqüicultura, Universidade Estadual de Maringá - UEM, \\ Av. Colombo, 5790, CEP 87020-900, Maringá, PR, Brazil \\ 'Instituto Nacional de Pesquisas da Amazônia,
}

Av. André Araújo, 2936, Aleixo, CEP 69060-001, Manaus, AM, Brazil

*e-mail: nadsonressye@yahoo.com.br

Received November 10, 2008 - Accepted March 4, 2009 - Distributed June 30, 2009

(With 2 figures)

\begin{abstract}
The integrity of aquatic ecosystems is being challenged worldwide by invading species, which has been one of the frequent causes of biodiversity loss. The invader may cause extinctions of vulnerable native species through predation, grazing, competition and habitat alteration. Daphnia lumholtzi G. O. Sars, 1885, a native cladoceran from Australia, Southwestern Asia and North Africa, has recently been found in the Neotropical region. The D. lumholtzi records from the Upper Paraná River floodplain were restricted to the Pombas floodplain lake (22 47' 55.92" S and

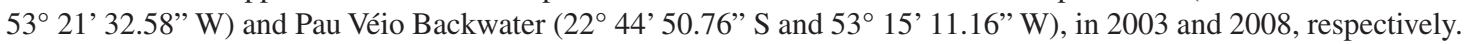
This species can be distinguished from the other Daphnia species registered in Brazil by the conspicuous pointed fornix, the sizes of the tail spine and helmet, and a carapace ventral margin with strong spines. The high temperatures in the tropical region, as well as the increase in water transparency and the decrease in nutrient concentration observed in the environments of the Upper Paraná River floodplain due to the upstream retention by dams, may favor the development of D. lumholtzi populations. The development of populations of D. lumholtzi in natural environments of the Upper Paraná River floodplain may suggest that this species is establishing in the Neotropical region.
\end{abstract}

Keywords: Daphnia lumholtzi, exotic species, neotropical, zooplankton.

\section{Espécie exótica de zooplâncton na planície de inundação do Alto Rio Paraná, Daphnia lumholtzi Sars, 1885 (Crustacea: Branchiopoda)}

\begin{abstract}
Resumo
A integridade dos ecossistemas aquáticos está sendo desafiada no mundo inteiro por espécies invasoras, as quais tem sido uma das causas freqüentes de perda de biodiversidade. Um invasor pode causar extinções de espécies nativas vulneráveis através de predação, herbivoría, competição e alteração de habitat. Daphnia lumholtzi G. O. Sars, 1885, cladócero nativo da Austrália, sudeste da Ásia e norte da África, recentemente tem sido registrado na região neotropoical. Os registros de D. lumholtzi na planície de inundação do Alto Rio Paraná foram restritos a lagoa das Pombas (22 47' 55.92" S e

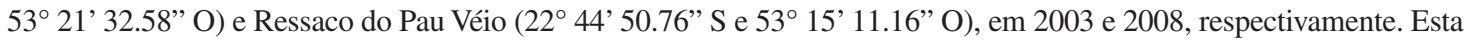
espécie pode ser diferenciada das demais espécies de Daphnia encontradas no Brasil pelos conspícuos fórnices pontiagudos, tamanho dos espinhos caudal e elmo, e margem ventral com espinhos fortes. As elevadas temperaturas na região tropical, o aumento da transparência da água e a redução das concentrações de nutrientes nos ambientes da planície de inundação do alto rio Paraná, devido aos represamentos a montante, podem estar favorecendo o desenvolvimento de populações de $D$. lumholtzi. O desenvolvimento de populações de $D$. lumholtzi em ambientes naturais da planície de inundação do alto rio Paraná pode representar o estabelecimento desta espécie na região neotropical.
\end{abstract}

Palavras-chave: Daphnia lumholtzi, espécie exótica, neotropical, zooplâncton.

\section{Introduction}

Species invasions represent one of the most urgent threats to the integrity of freshwater ecosystems (Havel et al., 2005a) since invaders may cause the extinction of vulnerable native species through predation, grazing, competition and habitat alteration (Mack et al., 2000). Thus, there is a growing need to understand the invasion process and to predict the success and effects of invading species (Moyle and Light, 1996) in order to 
identify future invaders and predict their likely sites of invasion (Mack et al., 2000). This impact has been frequently reported in the Neotropical region, where freshwater ecosystems are threatened by the introduction and dispersion of exotic species, resulting in environmental, social and economical damage, such as the invertebrate Limnoperna fortunei (Mollusca) (Karatayev et al., 2007; Sylvester et al., 2007).

Zooplankton fauna from temperate and tropical regions present a clear difference in size, with a predominance of larger species in the temperate region (Fernando, 1994). This difference can be explained by some hypotheses, such as size-selective predation: predation selectivity may exclude large zooplankton species from the environment (Brooks and Dodson, 1965). Recently, Daphnia lumholtzi G. O. Sars, 1885 (Crustacea: Branchiopoda), a native species cladoceran from Australia, Southwestern Asia and North Africa (Dumont, 1994) that has body proportions that are on average larger than those of tropical cladocerans was recorded in Brazil, in the Três Irmãos Reservoir, São Paulo State (Zanata et al., 2003). Since the first record of its presence in North America (Sorenson and Sterner, 1992), this species has displayed rapid dispersion in reservoirs across the United States (Havel and Medley, 2006). The impact of this species on the native fauna remains to be determined; experimental studies are necessary to evaluate its real impact on Brazilian aquatic ecosystems. Taking into account the size-efficiency feeding hypothesis (which proposes that larger species are more efficient at feeding on small particles) (Dodson, 1974), the establishment of D. lumholtzi populations may affect the native zooplankton biodiversity in Brazilian aquatic environments.

In the Neotropical region, 190 cladoceran species were recorded in different freshwater environments, and 98 species are endemics (Forró et al., 2008). In Brazil, approximately 140 species have already been recorded (Elmoor-Loureiro, 1997; 2007; Paggi and Rocha, 1999; Santos-Wisniewski, et al., 2001; Lopes et al., 2006; Sousa et al., 2008; Lansac-Tôha et al., 2009), although a large area of the territory, with various types of biotopes, has not yet been studied.

Cladocerans are an important group for the energy metabolism of aquatic ecosystems due to their intermediate position in the food chain, allowing them to be influenced by both top-down as well as bottom-up processes (Lampert, 1997). The Daphnia genus presents higher species numbers in temperate regions (Sendacz, 1993; Dumont, 1994). In Brazil, four species have already been recorded: Daphnia gessneri H. Herbst 1967, Daphnia leavis E. A. Birge 1878, Daphnia ambigua D. J. Scourfield 1947 and Daphnia lumholtzi G. O. Sars 1885. The first species has a wide geographic distribution in Brazil and is endemic to the South American region (Matsumura-Tundisi, 1984).

The cladoceran community from the Paraná River floodplain has been studied in the Argentine stretch since the 1970's (Paggi, 1995; Paggi and José de Paggi, 1990; 1974; José de Paggi, 1978), and in the Brazilian stretch since the 1980s (Lansac-Tôha et al., 1992; 1993; 1997; 2004; 2009; Sendacz, 1997; Serafim Jr. et al., 2003).

Biotic and abiotic aspects of rivers, floodplain lakes, channels and backwaters from the Upper Paraná River floodplain have been regularly monitored through Long Term Ecological Research (LTER/PELD-CNPq-site 6) started in 2000. Since then, about 70 cladoceran taxa have been registered, and Daphnia species (D. gessneri and D. leavis) occur in the study area (Lansac-Tôha et al., 2004). In addition to other cladocerans, these species have been an important food resource for fish larvae (Makrakis et al., 2008).

The distribution of $D$. lumholtzi in freshwater environments has been of great ecological interest since modeling their occurrence has contributed to an understanding of range expansion, the potential mechanisms of dispersal, and the effects of biological invasion, coexistence, competition and predation among zooplanktonic organisms (Dzialowski et al., 2000; Johnson and Havel, 2001; Lienesch and Gophen, 2001; Havel et al., 2002; Havel et al., 2005b; Havel and Medley, 2006). Thus, for a strategy of environmental conservation that will prevent future problems, it is important to characterize the occurrence and distribution of exotic species as well as the environmental conditions where they have been observed.

The present study sought to record the occurrence of $D$. lumholtzi, an exotic cladoceran species, in natural environments in the Upper Paraná River floodplain. We aimed to provide information about population size and the environmental conditions where they have been recorded, as well as some taxonomical characteristics.

\section{Materials and Methods}

The Upper Paraná River floodplain (Figure 1) $\left(22^{\circ} 30^{\prime}-22^{\circ} 00^{\prime} \mathrm{S}\right.$ and $\left.53^{\circ} 00^{\prime}-53^{\circ} 30^{\prime} \mathrm{W}\right)$ occupies an area superior to $802,150 \mathrm{~km}^{2}$ in Brazilian territory (Souza-Filho and Stevaux, 2004). In this floodplain, the diversity of aquatic biotopes comprises rivers, secondary channels, backwaters, tributaries with semi-lentic characteristics and temporary and permanent floodplain lakes (Agostinho et al., 2004).

Since 2000, cladocerans have been sampled in many different environments (rivers, connected and isolated floodplain lakes, secondary channels and backwaters) located in the three principal systems of this floodplain (Baía, Paraná and Ivinheima systems). Samplings were carried out every three months, at the subsurface, in the pelagic region of each environment, using a motorized pump and plankton net $(68 \mu \mathrm{m})$, filtering $600 \mathrm{~L}$ of water per sample. The samples were preserved in formaldehyde (4\%) solution, buffered with calcium carbonate. The specimens are deposited in the collection of the Zooplankton Laboratory (Nupélia/UEM).

Thirty D. lumholtzi individuals were collected to measure the total length, body length (base of tail spine to the superior portion of the eye), tail spine length and helmet (superior portion of the eye until the end of the 


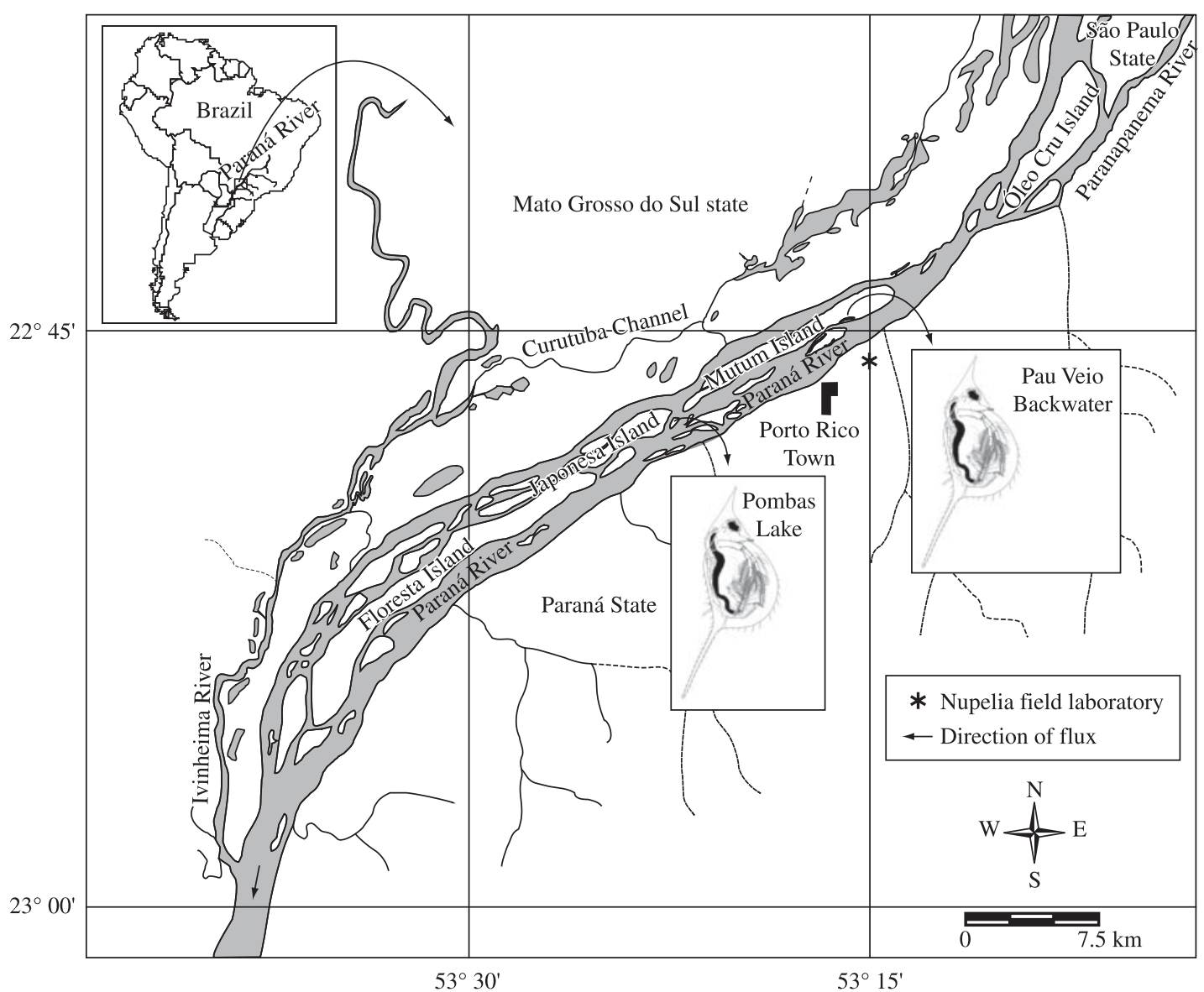

Figure 1. Upper Paraná River floodplain and site occurrence of Daphnia lumholtzi.

helmet). The measurements were taken at $125 \times$ magnification, using an optical binocular microscope fitted with an eyepiece micrometer.

Limnological data were furnished by Limnology Laboratory (Nupélia/UEM). The description of limnological factors in the Upper Paraná River floodplain and their temporal tendencies can be found in Roberto et al. (2009). We assessed the temporal tendencies of physical and chemical factors (2000-2008) in environments (Pau Véio Backwater) where quantitative samples of $D$. lumholtzi were obtained. These tendencies were measured by performing a Pearson correlation test and the significance level adopted was $\mathrm{p}<0.05$.

\section{Results}

\section{DAPHNIIDAE Straus, 1820}

Daphnia Muller, 1795

Daphnia lumholtzi Sars, 1885 (Figure 2)

Sars, 1885: 18, pl. 1, figs. 1-10; pl. 3-4; Nayar, 1971: 509, figs. 1-5; Nasar, 1977: 33, fig. 9; Fernando, 1980: 110; Smirnov and Timms, 1983: 93, fig. 108;
Benzie, 1988: 113-122, figs. 15-20; Havel and Hebert, 1993: 1824; Korinek, 2002: 77; Zanata et al., 2003: 717, fig. 2.

Diagnosis: Cephalic fornix laterally projected (Figure 2a, b). Ventral margin of carapace displayed strong spines (Figure 2a). Medium and distal region of dorsal margin and tail spine covered by spines (Figure 2a). Antennular mounds are well-developed and close to the rostrum. Claws with three pectens: a strong proximal pecten (Figure 2c), with the second and third decreasing distally. Second abdominal process is $1 / 3$ of the first, and the third one is $1 / 2$ of the second (in adult individuals) (Figure 2d). A detailed description of this species can be found in Benzie (1988).

Measurements (present study): Mean body width, $513 \mu \mathrm{m}( \pm 151)$, ranging from 250 to $840 \mu \mathrm{m}$. Mean body length, $842 \mu \mathrm{m}( \pm 197)$, ranging from 510 to $1160 \mu \mathrm{m}$. Tail spine ranged from 400 to $1,130 \mu \mathrm{m}$, with a ratio of body length/tail length ranging from 1.4 to 1.1 . In this case, the length of the tail spine can be equivalent to body length. Pronounced helmets pointed and slightly projected toward the front, ranging from 200 to $420 \mu \mathrm{m}$. 


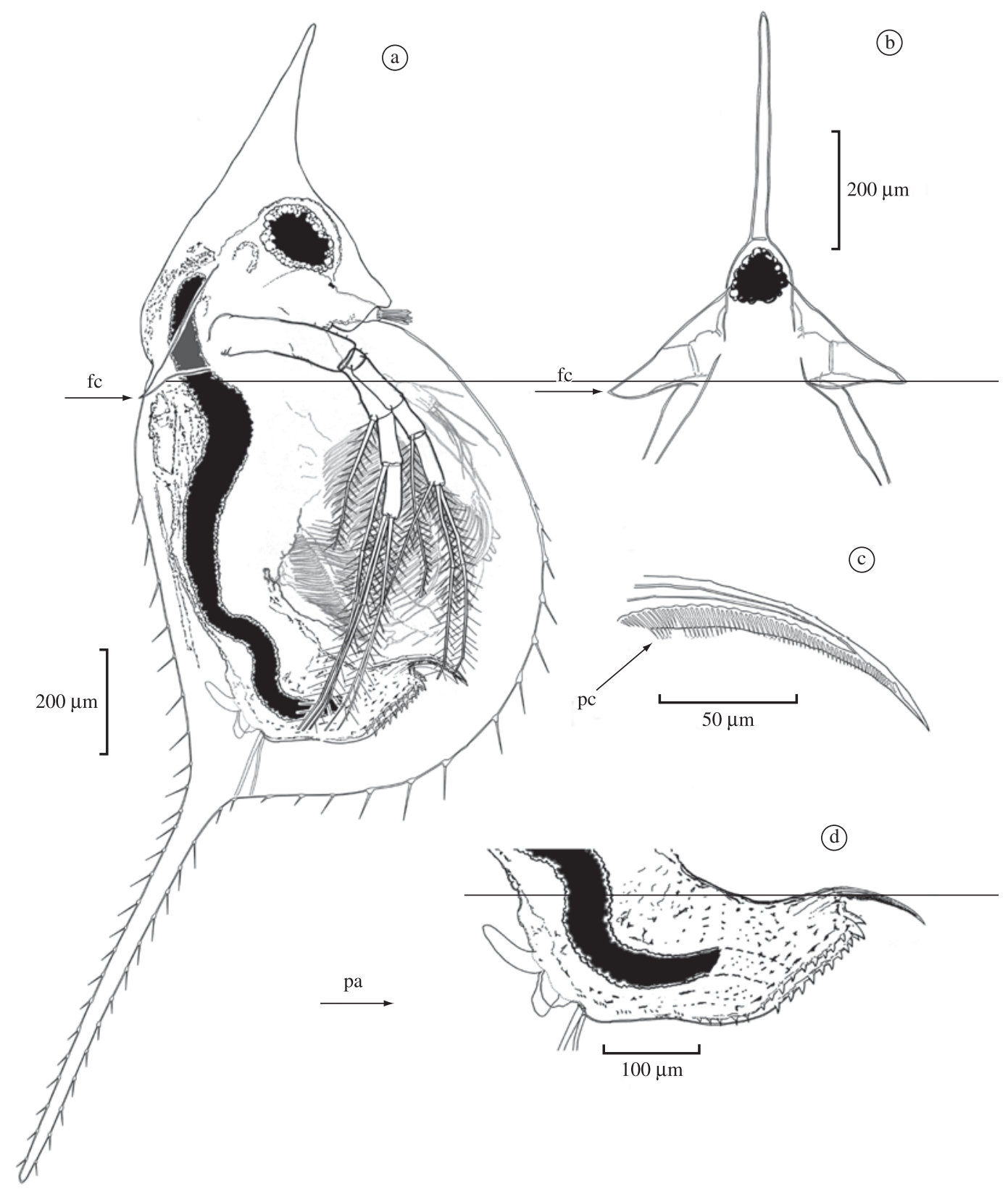

Figure 2. Daphnia lumholtzi collected in March/2008 in Pau Véio Backwater, Upper Paraná River Floodplain. a) General view; b) Front view of head; c) Claw; d) postabdomen. fc - fornix laterally projected; pa - abdominal process; $\mathrm{pc}$ - pectens.

The sum of body, helmet and tail spine lengths from D. lumholtzi specimens ranged from 1,130 to $2,710 \mu \mathrm{m}$.

Comments: Although the zooplankton community has been regularly sampled in different environments from the Upper Paraná River floodplain since 2000, $D$. lumholtzi was recorded, so far, in only two environments. The first record of this species was observed in qualitative samples from Pombas Lake (22 $2^{\circ} 47^{\prime} 55.92$ ' S and $53^{\circ} 21^{\prime} 32.58^{\prime \prime} \mathrm{W}$ ) in 2003 , during the potamophase period (Robertson, 2004); the other record occurred in
2008, in quantitative samples from the Pau Véio backwater $\left(22^{\circ} 44^{\prime} 50.76^{\prime \prime} \mathrm{S}\right.$ and $\left.53^{\circ} 15^{\prime} 11.16^{\prime \prime} \mathrm{W}\right)$ during the potamophase period, when we registered this species with a density of 442 ind. $\mathrm{m}^{-3}$ (1.5\% of the total cladoceran abundance).

Environmental conditions in the Pau Véio Backwater: the physical and chemical characteristics of the water displayed high variation throughout the period studied (Table 1). Among the variables presented in the literature as important for distribution of D. lumholtzi, Secchi 
Table 1. Summary of limnological features in the Pau Véio Backwater from 2000 to 2008. *Significant positive correlation with time; **Significant negative correlation with time.

\begin{tabular}{lcrcc}
\hline & Minimum & Maximum & Mean & March/2008 \\
\hline Water temperature $\left({ }^{\circ} \mathrm{C}\right)$ & 17.30 & 31.30 & 25.19 & 27.0 \\
Dissolved oxygen $\left(\mathrm{mg} . \mathrm{L}^{-1}\right)$ & 0.97 & 8.65 & 5.28 & 3.3 \\
pH & 5.87 & 7.40 & 6.58 & 6.71 \\
Electric conductivity $\left(\mu \mathrm{S} . \mathrm{cm}^{-1}\right)$ & 47.00 & 69.70 & 56.95 & 67.2 \\
Total alkalinity $\left(\mathrm{mEq} . \mathrm{L}^{-1}\right)$ & 44.10 & 775.30 & 351.74 & 370.7 \\
$*$ Secchi disc $(\mathrm{m})$ & 0.75 & 3.50 & 1.87 & 2.25 \\
Turbidity $(\mathrm{NTU})$ & 0.30 & 18.60 & 4.40 & 5.46 \\
Total solids suspended $\left(\mathrm{mg} . \mathrm{L}^{-1}\right)$ & 0.50 & 4.00 & 1.82 & 2.2 \\
$* *$ Chlorophyll- $a\left(\mu \mathrm{g} . \mathrm{L}^{-1}\right)$ & 0.27 & 22.70 & 4.68 & 4.1 \\
$*$ Total nitrogen $\left(\mu \mathrm{g} . \mathrm{L}^{-1}\right)$ & 85.68 & 975.20 & 371.86 & 922.3 \\
Nitrite $\left(\mu \mathrm{g} . \mathrm{L}^{-1}\right)$ & 0.00 & 163.20 & 72.06 & 82.9 \\
Total phosphorus $\left(\mu \mathrm{g} . \mathrm{L}^{-1}\right)$ & 8.43 & 48.78 & 17.41 & 21.3 \\
Phosphate $\left(\mu \mathrm{g} . \mathrm{L}^{-1}\right)$ & 0.00 & 13.12 & 4.37 & 8.8 \\
\hline
\end{tabular}

disc, chlorophyll- $a$ and total nitrogen showed significant changes with time: water transparency and total nitrogen increased, while chlorophyll $a$ content diminished. These trends reflect changes in physical and chemical conditions of the water, which may be favoring the development of $D$. lumholtzi populations.

\section{Discussion}

Daphnia lumholtzi can be distinguished from the other Daphnia species registered in Brazil (MatsumuraTundisi, 1984) by the conspicuous pointed fornix, size of the tail spine and helmet, ventral margin of carapace with strong spines and subrectangular postabdomen with a terminal claw that is slightly curved with three pectens. When compared to the body length of $D$. gessneri (1,170 $\mu \mathrm{m}$, Castilho-Noll and Arcifa, 2007), D. lumholtzi presents similar values for body size. However, its helmet, tail spine and lateral projection are larger than those observed for D. gessneri.

In the Neotropical region, D. lumholtzi was first recorded in 2000, at Três Irmãos Reservoir (São Paulo, Brazil), with density varying from 55 ind. $\mathrm{m}^{-3}$ in the transition region to 100 ind. $\mathrm{m}^{-3}$ in the lacustrine region (Zanata et al., 2003). In the Upper Paraná River floodplain, D. lumholtzi was registered in 2003 (Pombas floodplain lake) (Roberston, 2004); only after five years (2008) was it recorded in Pau Véio backwater, with the highest density observed in the Neotropical region (442 ind. $\mathrm{m}^{-3}$ ). Both environments are shallower, with mean depth of $3.3 \mathrm{~m}$ (Pombas floodplain lake) and $1.8 \mathrm{~m}$ (Pau Véio backwater).

In the native area, D. lumholtzi inhabits several aquatic biotopes: lakes, floodplains, and dams (Benzie, 1988). The first records in North America (United States of America) were obtained from reservoirs; then the species showed an effective dispersal (colonization) to natu- ral environments in the same basin, such as large rivers, swamps, and natural lakes (Havel and Medley, 2006). Thus, the reservoirs act as stepping-stones for the dispersal of D. lumholtzi across landscapes that promoted the invasion process due to their physiochemical properties, greater connectivity, and higher levels of disturbance (Havel et al., 2005a). The same situation currently seems to be occurring in South America.

In Brazil, D. lumholtzi has been recorded in different environments associated with the Paraná River (reservoir, floodplain lake and backwater), suggesting that the river serves as a passive vector for dispersal of this species. Other regions in Brazil should be studied regularly to increase the knowledge of this dispersal pattern since $D$. lumholtzi uses rivers as corridors for migration into downstream reservoirs and river floodplains (Havel and Medley, 2006).

The Paraná River Basin has 26 reservoirs (of more than $100 \mathrm{~km}^{2}$ each) built upstream from the floodplain (Agostinho et al., 2008); the last one built was the Porto Primavera Dam in 1998 (30 km upstream of the study area). This reservoir improved control of the previous discharge regime of the Paraná River which, in turn, impacts the limnological conditions of the environments downstream, including the Upper Paraná River floodplain. The dam obstructed suspended sediment transport, increasing river transparency and reducing nitrogen and phosphorus concentrations (Thomaz et al., 2004; Roberto et al., 2009). Thus, the river water quality in the connected environments of the floodplain has been changed, likely due to the upstream cascade of reservoirs (Roberto et al., 2009).

D. lumholtzi exhibits tolerance to a wide range of environmental conditions, allowing the species to reach new habitats (Dzialowski et al., 2000; Acharya et al., 2006). However, D. lumholtzi obtained greatest colonization success under high temperatures, great transparency, and 
low levels of nitrogen and phosphorus (Work and Gophen 1999a, b; Dzialowski et al., 2000; Lennon et al., 2001; Havel et al., 2005b). These limnological conditions were observed in the environments connected to the Paraná River which have been invaded by $D$. lumholtzi

These records and increased population size demonstrate the establishment of this species in the Neotropical region. High temperatures in the tropical region, especially during the summer, in combination with increased water transparency and decreased nutrient concentration in the Upper Paraná River floodplain, may favor D. lumholtzi development. The success of other exotic species in this floodplain, such as the fish Cichla kelberi (Abujamra, 2007) and the aquatic macrophyte Hydrilla verticillata (Thomaz et al., 2009), has been associated with the increase in water transparency in floodplain environments.

The morphological features of $D$. lumholtzi may also have contributed to population size increases. This species has long spines and projections in its head that are peculiar because they reduce the vulnerability to predation by planktivorous fishes and invertebrates, furnishing an advantage over other Daphnia species (Lagergren et al., 2007). However, Johnson and Havel (2001) observed that D. lumholtzi may coexist with other daphniids, in temperate regions due to little seasonal overlap with native daphniids. These authors verified that higher densities, biomass and birth rates among $D$. lumholtzi occur only during the summer when there is a decrease in the density of other daphniids that are not adapted to high temperatures. Similar results were also found by Lienesch and Gophen (2001), who stated high abundances of $D$. lumholtzi during the summer when the density of native organisms was low; such conditions favored certain zooplanktivorous fishes through the increase in foraging opportunities during a period with low prey availability. According to Acharya et al. (2006), such life history may be linked to the tropical/subtropical origin of $D$. lumholtzi, including adaptations to survival in dry conditions.

D. lumholtzi invasion in Brazil was observed in artificial and natural environments in the Paraná River Basin; however, $D$. lumholtzi dispersal and the consequent distribution pattern were not clear because records were not obtained frequently. This species seems to have achieved the abiotic requirements necessary to survive, but has struggled to remain in the water column (indicating the transposition of biogeographical and physiological filters, Espindola and Julio Jr., 2007) in the Neotropical region. Meanwhile, its success is determined by interactions with local species, through competition and predation (biotic filter). Once the species is successful in establishing its presence, significant changes may occur in the structure of local aquatic communities, although these changes are unpredictable.

Acknowledgements - We thank the Limnology Laboratory of Nupelia for providing us with limnological data. We also wish to express our gratitude to CNPq (PELD-site 6) and Nupélia for financial and logistical support, and to CNPq for scholarship funds.

\section{References}

ABUJAMRA, F., 2007. Influências do controle de nível $e$ transparência da água impostos pela formação do reservatório de Porto Primavera sobre peixes de diferentes categorias tróficas do alto rio Paraná. Maringá: Universidade Estadual de Maringá - UEM. 38p. Tese de Doutorado.

ACHARYA, K., JACK, JD. and SMITH, AS., 2006. Stoichiometry of Daphnia lumholtzi and their invasion success: are they linked?. Archiv fur Hydrobiologie, vol. 154, no. 4, p. $433-453$.

AGOSTINHO, AA., PELICICE, FM. and GOMES, LC., 2008. Dams and the fish fauna of the Neotropical region: impacts and management related to diversity and fisheries. Revista Brasileira de Biologia = Brazilian Journal of Biology, vol. 68, no. 4, p. 1119-1132.

AGOSTINHO, AA., THOMAZ SM. and GOMES, LC., 2004. Threats for biodiversity in the floodplain of the Upper Paraná River: effects of hydrological regulation by dams. Ecohydrology \& Hydrobiology, vol. 4, no. 3, p. 255-268.

BENZIE, JAH., 1988. The systematics of Australian Daphnia (Cladocera: Daphniidae): species descreptions and keys. Hydrobiologia, vol. 166, no. 3, p. 95-191.

BROOKS, JL. and DODSON, SI., 1965. predation, body size, and composition of plankton. Science, vol. 150, no. 3692, p. 28-35.

CASTILHO-NOLL, MSM. and ARCIFA, MS., 2007. Lengthweight relationships for zooplanktonic species of a tropical Brazilian lake: lake Monte Alegre. Acta Limnologia Brasiliensia, vol. 19 , no. 1, p. 93-100.

DODSON, SI., 1974. Zooplankton competition and predation: an experimental test of the size-efficiency hypothesis. Ecology, vol. 55 , no. 3, p. $605-913$.

DUMONT, HJ., 1994. On the diversity of the Cladocera in the tropics. Hydrobiologia, vol. 272, no. 1-3, p. 27-38.

DZIALOWSKI, AR., O'BRIEN, WJ. and SWAFFAR, M., 2000. Range expansion and potential mechanisms of the exotic cladoceran Daphnia lumholtzi. Journal of Plankton Research, vol. 22 , no. 12 , p. $2205-2223$.

ELMOR-LOUREIRO, LMA., 1997. Manual de identificação de cladóceros límnicos do Brasil. Brasília: Editora Universa. $155 \mathrm{p}$.

,2007. Phytophilous cladocerans (Crustacea,Anomopoda and Ctenopoda) from Parana River Valley, Goiás, Brazil. Revista Brasileira de Zoologia, vol. 24, no. 2, p. 344-352.

ESPINDOLA, LA. and JULIO Jr., HF., 2007. Espécies invasoras: conceitos, modelos e atributos. Interciencia, vol. 32, no. 9 , p. 580-585.

FERNANDO, CH., 1980. The freshwater zooplankton of Sri Lanka, with a discussion of tropical freshwater zooplankton composition. Internationale Revue der Gesamten Hydrobiologie, vol. 65 , no. 3 , p. 85-125.

1994. zooplankon, fish and fisheries in tropical freshwaters. Hydrobiologia, vol. 272, no. 1-3, p. 105123.

FORRÓ, L., KOROVCHINSKY, NM., KOTOV, AA. and PETRUSEK, A., 2008. Global diversity of cladocerans 
(Cladocera; Crustacea) in freshwater. Hydrobiologia, vol. 595, no. 1, p.177-184.

HAVEL, JE. and HEBERT, PDN., 1993. Daphnia Lumholtzi in North America: another exotic zooplankton. Internationale Revue der Gesamten Hydrobiologie, vol. 38, no. 8, p. 18231827.

HAVEL, JE. and MEDLEY, KA., 2006. Biological invasions across spatial scales: intercontinental, regional, and local dispersal of cladoceran zooplankton. Biological Invasions, vol. 8, no. 3, p. 459-473.

HAVEL, JE., LEE, CE. and ZANDEN, JV., 2005a. Do reservoirs facilitate invasions into landscapes? BioScience, vol. 55, no. 6, p. 518-525.

HAVEL, JE., SHURIN, JB and JONES, JR., $2005 \mathrm{~b}$. Environmental limits to a rapidly spreading exotic cladoceran. Ecoscience, vol. 12, no. 3, p. 376-385.

2002. Estimating dispersal from patterns of spread: spatial and local control of lake invasions. Ecology, vol. 83, no. 12 , p. 3306-3318.

JOHNSON, JL. and HAVEL, JE., 2001. Competition between native and exotic Daphnia: in situ experiments. Journal of Plankton Research, vol. 23, no. 4, p. 373-387.

JOSÉ de PAGGI, S., 1978. First observations on longitudinal sucession of zooplankton in the main course of the Paraná river between Santa Fe and Buenos Aires harbour. Studies on Neotropical Fauna and Environment, vol. 13, p. 157-194.

KARATAYEV, AY., PADILLA, DK., MINCHIN, D., BOLTOVSKOY, D., BURLAKOVA, LE. and LYUBOV, E., 2007. Changes in global economies and trade: the potential spread of exotic freshwater bivalves. Biological Invasions, vol. 9 , no. 2 , p. 161-180.

KORINEK, V., 2002. Cladocera. In FERNANDO, CH. (Ed.). A guide to tropical freshwater zooplankton: identification, ecology and impact fisheries. Leiden: Backhuys Publishers. p. 69-122.

LAGERGREN, R., SVESSON, JK. and STENSON, JAE., 2007. Models of ontogenetic allometry cladoceran morphology studies. Hydrobiologia, vol. 594, no. 1, p. 109-116.

LAMPERT, W., 1997. Zooplankton research: the contribution of limnology to general ecological paradigms. Aquatic Ecology, vol. 31, no. 1, p. 19-27.

LANSAC-TÔHA, FA., BONECKER, CC. and VELHO, LFM., 2004. Composition, species richness and abundance of zooplankton community. In Thomaz, SM., Agostinho, AA. and Hahn, NS. (Eds.). The Upper Paraná river and its floodplain: physical aspects, ecology and conservation. Leiden: Backhuys Publishers. p. 145-190.

LANSAC-TÔHA, FA., BONECKER, CC., VELHO, LFM. and LIMA, AF., 1997. Composição, distribuição e abundância da comunidade zooplanctônica. In Vazoller, AEAM., Agostinho, AA. and Hann, NS. (Eds.). A planície de inundação do alto Rio Paraná: aspectos físicos, biológicos e socioeconômicos. Maringá: EDUEM. p. 117-177.

LANSAC-TÔHA, FA., BONECKER, CC., VELHO, LFM., SIMÕES, NR., DIAS, JD., ALVES, GM. and TAKAHASHI, EM., 2009. Biodiversity of zooplankton community in the Upper Paraná river floodplain: interannual variation from longterm studies. Revista Brasileira de Biologia = Brazilian Journal of Biology, vol. 69, no. (2 suppl), p. 539-549.
LANSAC-TÔHA, FA., LIMA, AF., THOMAZ, SM. and ROBERTO, MC., 1992. Zooplâncton de uma planície de inundação do rio Paraná. I. Análise qualitativa e estrutura da comunidade. Revista Unimar, vol. 14, (Supl.), p. 35-55

1993. Zooplâncton de uma planície de inundação do rio Paraná. II. Variação sazonal e influência dos níveis fluviométricos sobre a comunidade. Acta Limnologica Brasiliensia, vol. 6, p. 42-55.

LENNON, JT., SMITH, VH. and WILLIAMS, K., 2001. Influence of temperature on exotic Daphnia limholtzi and implications for invasion success. Journal of Plankton Research, vol. 23 , no. 4 , p. $425-434$.

LIENESCH, PWL. and GOPHEN, MG., 2001. Predation by inland silversides on an exotic cladoceran, Daphnia lumholtzi, in Lake Texoma, U.S.A. Journal of Fish Biology, vol. 59, no. 5, p. $1249-1257$.

LOPES, PM., ELMOOR-LOUREIRO, LMA. and BOZELLI, RL. 2006. First record of Dunhevedia colombiensis Stingelin, 1913 (Cladocera, Anomopoda, Chydoridae) from Brazil. Revista Brasileira de Biologia = Brazilian Journal of Biology, vol. 66, no. 4, p. 1141-1142.

MACK, RN., SIMBERLOFF, D., LONSDALE, WM., EVANS, H., CLOUT, M. and BAZZAZ, F., 2000. Biotic Invasions: causes, epidemiology, global consequences and control. Issues in Ecology, vol. 5, p. 1-20.

MAKRAKIS, MC., NAKATANI, K., BIALETZKI, A., GOMES, LC., SANCHES, PV. and BAUMGARTNER, G., 2008. Relationship between gape size and feeding selectivity of fish larvae from a Neotropical Reservoir. Journal Fish of Biology, vol. 72, no. 7, p. 1690-1707.

MATSUMURA-TUNDISI, T., 1984. Occurrence of species of the genus Daphnia in Brazil. Hydrobiologia, vol. 122, no. 3, p. $161-165$.

MOYLE, PB. and LIGHT, T., 1996. Biological invasions of fresh water: empirical rules and assembly theory. Biological Conservation, vol. 78, no. 1, p. 149-161.

NASAR, SAK., 1977. The zooplankton fauna of Bliagalpar (Bihar). II Cladocera. Researches Crustacean, vol. 8, p. 32-36.

NAYAR, CKG., 1971. Cladocera of Rajastham. Hydrobiologia, vol. 37 , no. 3-4, p. 509-519.

PAGGI, JC. and JOSÉ DE PAGGI, S., 1974. Primeros estúdios sobre el zooplancton de las águas lóticas del Paraná médio. Physis, vol. 33, no. 86, p. 91-114.

1990. Zooplâncton de ambientes lóticos e lênticos do Rio Paraná médio. Acta Limnologica Brasiliensia, vol. 3, no. 2, p. 685-719.

PAGGI, JC. and ROCHA, CEF., 1999. Neodiaphanosoma a new genus of Sididae (Branchiopoda, Ctenopoda); with description of $N$. bergamini sp. n. and comments on $N$. volzi (Stingelin 1905). Hydrobiologia, vol. 397, no. 1, p. 5-19.

PAGGI, JC., 1995. Crustacea: Cladocera: clave para determiner gêneros de cladocera registrados em na region neotropical. In Lopretto, EC. and Tell, G. (Eds.). Ecossistemas de água continentales: metodologia para su estúdio. La Plata: Ediciones Sur. p. 909-951.

ROBERTO, MC., SANTANA, NF. and THOMAZ, SM., 2009. Limnology in the Upper Paraná river floodplain: large-scale 
spatial and temporal patterns, and the influence of reservoirs. Revista Brasileira de Biologia = Brazilian Journal of Biology, vol. 69, no. (2 suppl), p. 717-725.

ROBERTSON, BA., 2004. Riqueza de espécies de cladocera (Crustacea) em lagoas da planície de inundação do alto rio Paraná: amostragem e estimativas. Maringá: Universidade Estadual de Maringá. 30p. Tese de Doutorado.

SANTOS-WISNIEWSKI, MJ., ROCHA, O. and MATSUMURA-TUNDISI, T., 2001. First record of Alona setifera Brehm (Cladocera, Chydoridae) in the Neotropical region. Revista Brasileira de Biologia $=$ Brazilian Journal of Biology, vol. 61, no. 4, p. 701-702.

SARS, GO., 1885. On some Australian Cladocera raised from dried mud. Furhandlinger $i$ Videnskabs - Selskaber I Christiania, vol. 8, p. 1-46.

SENDACZ, S., 1993. Distribuição geográfica de alguns organismos zooplanctônicos na América do Sul. Acta Limnologica Brasiliensia, vol. 6, p. 31-41.

1997. Zooplankton studies of floodplain lakes of the Upper Paraná river, São Paulo State, Brazil. Verhandlungen Internationale Vereinigung für Theoretische und Angewandte Limnologie, vol. 26, p. 621-627.

SERAFIM, Jr., M., LANSAC-TÔHA, FA., PAGGI, JC., VELHO, LFM. and ROBERTSON, B., 2003. Cladocera fauna composition in a river-floodplain lake system of the upper Paraná river floodplain, with a new record Brazil. Revista Brasileira de Biologia = Brazilian Journal of Biology, vol. 63, no. 2, p. 349-356.

SMIRNOV, NN. and TIMMS, BV., 1983. A revision of the Australian Cladocera (Crustacean). Records of the Australian Museum, vol. 1, Suppl., p. 1-132.

SORENSON, KH. and STERNER, RW., 1992. Extreme cyclomorphosis in Daphnia lumholtzi. Freshwater Biology, vol. 28 , no. 2 , p. $257-262$.
SOUSA, FDR. and ELMOOR-LOUREIRO, LMA., 2008. Cladóceros fitófilos (Crustacea, Branchiopoda) do Parque Nacional das Emas, estado de Goiás. Biota Neotropica, vol. 8, no. 1 , p. 159-166.

SOUZA-FILHO, EE. and STEVAUX, JC., 2004. Geology and geomorphology of the Baía-Curutuba-Ivinheima river complex. In Thomaz, SM., Agostinho, AA. and Hahn, NS. (Eds.). The Upper Paraná river and its floodplain. Leiden: Backhuys Publishers. p. 1-30.

SYLVESTER, F., BOLTOVSKOY, D. and CATALDO, DH., 2007. Fast response of freshwater consumers to a new trophic resource: predation on the recently introduced Asian bivalve Limnoperna fortunei in the lower Paraná river, South América. Austral Ecology, vol. 32, no. 4, p. 403-415.

THOMAZ, SM., CARVALHO, P., PADIAL, AA. and KOBAYASHI, JT., 2009. Temporal and spatial patterns of aquatic macrophyte diversity in the Upper Paraná River floodplain. Revista Brasileira de Biologia = Brazilian Journal of Biology, vol. 69, no. (2 suppl), p. 617-625.

THOMAZ, SM., PAGIORO, TA., BINI, LM., ROBERTO, MC. and ROCHA, RRA., 2004. Limnology of the Upper Paraná floodplain habitats: patters of spatio-temporal variations and influence of the water leves. In Agostinho, AA., Rodrigues, L., Gomes, LG., Thomaz, SM. and Miranda, LE. (Eds.). Structure and functioning of the Paraná river and its floodplain. Maringá: EDUEM. p. 39-42.

WORK, K. and GOPHEN, M., 1999a. Factors which affect the abundance of an invasive cladoceran, Daphnia lumholtzi, in U.S. reservoirs. Freshwater Biology, vol. 42, no. 1, p. 1-10.

1999b. Environmental variability and the population dynamics of the exotic Daphnia lumholtzi and native zooplankton in Lake Texoma, U.S.A. Hydrobiologia, vol. 405, no. 1, p. $11-23$

ZANATA, LH., ESPINDOLA, ELG., ROCHA, O. and PEREIRA, RHG., 2003. First record of Daphnia lumholtzi Sars, 1885, exotic cladoceran, in São Paulo state (Brazil). Revista Brasileira de Biologia = Brazilian Journal of Biology, vol. 63, no. 4, p. 717-720. 